\title{
APSA Awards Presented at the 2014 Annual Meeting
}

$\mathrm{R}$ ecognizing excellence in the profession is one of the most important activities of the American Political Science Association. The association's Annual Awards Ceremony and Luncheon was held Thursday, August 28, 2014, at the Annual Meeting in Washington, DC.

\section{CAREER AWARDS}

\section{Frank J. Goodnow Award}

The Goodnow Award recognizes distinguished service to the profession and the Association, by necessarily a career of scholarship. This service may be by individuals, groups, and public and private organizations who have played a role in the development of the political science profession and the building of the American Political Science Association.

Award Committee: Michelle D. Deardorff, University of Tennessee at Chattanooga, Chair; Virginia Sapiro, Boston University; C. Danielle Vinson, Furman University

The 2014 Frank Goodnow Award for Distinguished Service is awarded to three distinguished political scientists, whose careers have resulted in the discipline becoming more inclusive in terms of methodologies and membership, resulting in new research questions and stronger scholarship.

Recipient: David Collier, University of California, Berkeley

Citation: David Collier of the University of California, Berkeley, is being recognized for his leadership in the development of qualitative methodology within the discipline. He has chaired the Academic Council of the Consortium for the Qualitative Research Methods for over a decade, served on the Advisory Board of the Standing Group on Political Methodology of the European Consortium for Political Research, and is the Founding President of the APSA Organized Section for Qualitative and Multi-Method Research. In his nomination, he was recognized as "a driving force to make sure that qualitative methods were given their due within political science and to make sure that qualitative methodologists developed a research program to explicate and improve their methods." This work has been accomplished through his research, his co-edited book Rethinking Social Inquiry, his consistent organization and sponsorship of short courses at the APSA meetings, and more importantly, through his work to create the Organized Section for Qualitative and MultiMethod Research. In addition, David Collier has been central to the efforts to institutionalize the Consortium for Qualitative Research Methods-a multi-week teaching and research enterprise designed to provide opportunities for students and faculty to learn about qualitative methods and improve upon them. David Collier has also served as president of the Organized Section for Comparative Politics, vice-president of APSA, and as a member of the APSA Task Force on Graduate Education in Political Science. David Collier's work in the discipline was recognized in 2004 by his election to the American Academy of Arts and Sciences.

Recipient: John E. Jackson, University of Michigan

Citation:John E. Jackson of the University of Michigan is being honored for service to his profession through his important role in establishing political methodology as a core subfield field of political science. In 1984, John Jackson organized the first "Summer Meeting" of the Society for Political Methodology with about a dozen people attending. Now this annual conference attracts about 200 people, a thousand subscribe to the methods listserv and the methods section is now the second largest of all APSA sections. The first summer meetings were faculty-only affairs, but his argument that the field's future lay in incorporating graduate students in a serious way held sway, and the political methodology meeting became famous for doing just that. Every graduate student at the meeting was given a mentor, and John is famous for his investment in these young people time after time. He helped to found the respected journal, Political Methodology. Not surprisingly, he was selected to the inaugural class of Fellows of the Society for Political Methodology, and he received the Career Achievement Award from the Society. John Jackson's scholarly, teaching, and professional achievements have been multiply recognized, most broadly by his election to the American Academy of Arts and Sciences in 2008. His department awarded him with the Tronstein Prize for Innovative Teaching in 2009. He chaired his department and was Vice President of APSA among many other positions. John Jackson richly deserves the Goodnow Award.

Recipient: Ronald Schmidt, California State University, Long Beach

Citation: Ronald Schmidt, Professor Emeritus of California State University, Long Beach, is being recognized for his "tireless institution-building efforts" in political science at the national, regional, and local levels. In the American Political Science Association, he was a key participant in the establishment of the organized section on Race, Ethnicity, and Politics, serving as section President, and he was a member of the APSA Committee on the Status of Latinas and Latinos in the Profession. He has been a member of the Editorial Board of the American Political Science Review and PS: Political Science and Politics, as well as served on numerous awards committees. In the Western Political Science Association, Ronald Schmidt has served as President and as a member of the Long Range Planning Committee, he helped the WSPA develop a long-term financial plan and launch the journal Politics, Groups and Identities. $\mathrm{He}$ has served the profession with a strong commitment to mentoring "low income, first generation, and underrepresented students to prepare them for doctoral work," participating in the California State University Sally Casanova Pre-Doctoral Fellows Program, the McNair Scholars Program, and the "Partners for Success" Program. He has taken his concern for student education beyond 
his own campus and served as a member of the APSA Task Force on Mentoring and the Education Committee. Ronald Schmidt has demonstrated throughout his career a "fundamental belief in the importance of the collective enterprise," and his colleagues praise his consistent commitment to "improving the health and vibrancy of every collective space in which he has participated."

\section{John Gaus Award and Lectureship}

The John Gaus Award and Lectureship honors the recipient's lifetime of exemplary scholarship in the joint tradition of political science and public administration and, more generally, recognizes and encourages scholarship in public administration.

Award Committee: Guy Peters, University of Pittsburgh, Chair; Jared Llorens, Louisiana State University; Saundra K. Schneider, Michigan State University

Recipient: Barbara Romzek, American University

Citation: The American Political Science Association (APSA) is proud to confer the 2013 John Gaus award upon Professor Barbara Romzek, to honor her "lifetime of exemplary scholarship in the joint tradition of political science and public administration."

Barbara Romzek is Dean of the School of Public Affairs at American University. She has made numerous important contributions to multiple streams of public administration and political science literature. Her research on accountability has been particularly important in the development of contemporary thinking about the control of public organizations, and the complex patterns of interaction involved in contemporary accountability. She has also made significant contributions to research on public sector reform, government contracting, and the role of policy networks in service delivery.

Romzek has authored or coauthored three books and several dozen articles and book chapters. His scholarship has appeared in leading public administration and political science outlets and has been recognized with best article awards from Public Administration Review. She has also received a number of rewards for scholarship and professional service. She has been active on a number of editorial boards and in professional associations.

Romzek's prolific record of scholarly achievement, sustained for over 30 years in academia, epitomizes the lifetime of exemplary scholarship envisaged by APSA for the John Gaus Distinguished Lecturer Award.

\section{Hubert H. Humphrey Award}

The Hubert H. Humphrey Award is awarded annually in recognition of notable public service by a political scientist.

Award Committee: Kathryn Sikkink, University of Minnesota, Chair; Hahrie C. Han, Wellesley College; Adolph L. Reed, Jr., University of Pennsylvania

Recipient: Representative Henry Cuellar (D-TX 28), United States House of Representatives

Citation: Henry Cuellar, the son of migrant workers who never made it past the fifth grade, has often described himself as "the most degreed member of Congress." Cuellar earned his associate's degree in political science from Laredo Community College in 1976, and then enrolled in Georgetown University in Washington, DC, where he graduated cum laude with a BA in foreign service. While attending Georgetown, he washed dishes and worked other jobs to pay for his college tuition. Returning to Texas, Congressman Cuellar completed a master's degree in international irade at Texas A\&M International University and earned a law degree and $\mathrm{PhD}$ in government from the University of Texas at Austin. From 1982 to 1986 , he worked as an instructor in the department of government at Laredo Community College.

In the mid-1980s, Congressman Cuellar decided to fully dedicate his life to public service and served as a Texas State Representative from 1987 until he was appointed as the Texas Secretary of State in 2001. As Secretary of State, he initiated policies to register, educate, and protect voters' rights. In 2005, Congressman Cuellar was elected to represent the 28th District of Texas in Washington, DC. Congressman Cuellar is widely recognized as a leader on border security, immigration reform, and homeland security issues. Cuellar is a nember of the Congressional Hispanic Caucus, and he serves as a member of the Board of Advisers of the Texas Hispanic Journal of Law and Policy.

\section{James Madison Award and Lectureship}

The James Madison Award recognizes an American political scientist who has made a distinguished scholarly contribution to political science.

Award Committee:James E. Alt, Harvard University, Chair; Judith Lynn Goldstein, Stanford University; Gary C. Jacobson, University of California, San Diego
Recipient: Robert Keohane, Princeton University

Citation: After consideration of the contributions of many very fine scholars, the committee is delighted to select Robert Keohane for the 2014 James Madison Award and Lectureship. The award recognizes Keohane as the complete scholar: he has written extensively in the field of international politics, creating a field around himself; he has educated and mentored generations of students, especially women; and he has served the discipline, both through his many years of departmental service but also through his long commitment to the association. Keohane is a scholar of international politics whose work focuses on the determinants of cooperation between nations and within international organizations. His most-cited work, After Hegemony: Cooperation and Discord in the World Political Economy, asked whether and how nations can agree to solve common problems in a world lacking a leading power. Other well-known works, whose title describe the range of his ongoing, concerns, include Designing Social Inquiry (coauthored with Gary King and Sidney Verba) and Power and Interdependence (coauthored with Joseph S. Nye, Jr.). Each of these has had a significant and continuing influence on scholarship in international relations long after original publication; each share a common vision that nations can work together to solve even the most intractable problems, which in his long career has ranged from fundamental problems of market failures to the legal protections of human rights. Keohane's influence in the discipline extends not only to his own scholarship but also to his decades-long association with International Organization. As one committee member noted, Keohane "created a field, and a journal, and a generation of students to follow up on his ideas." His Madison address promises to build on his recent work on institutions in international relations. In these well-crafted analyses of problems associated with the commons -sources of future energy, environmental degradation, and climate change-Keohane offers an explanation for policy choice and an agenda of options for future cooperation.

\section{Carey McWilliams Award}

The Carey McWilliams Award is given annually to honor a major journalistic contribution to our understanding of politics.

Award Committee: Diana M. Owen, Georgetown University, Chair; Melissa V. Harris-Perry, Tulane University; Daron R. Shaw, University of Texas 
Recipient: Charlayne Hunter-Gault, journalist

Citation: It is with deep respect and sincere appreciation that the American Political Science Association awards the 2014 Cary McWilliams Prize to Charlayne HunterGault. The McWilliams Prize honors a person who has made outstanding journalistic contributions to our understanding of politics. Ms. Hunter-Gault's path-breaking career has encompassed many aspects of the field of journalism in print, on radio and television, and online. She has covered national and global events ranging from the civil rights movement in the U.S. to apartheid in South Africa. Her own story has contributed profoundly to our country's civil rights history.

Ms. Hunter-Gault epitomizes the intellectual forthrightness and political independence that were the essence of Cary McWilliams. She shares McWilliams' concern for social issues, dedication to promoting racial equality, and willingness to act to protect civil rights and liberties. Both endured hardship in the pursuit of justice.

Ms. Hunter-Gault developed an interest in journalism at an early age. After graduating from the prestigious Henry McNeal Turner High School in Atlanta near the top of her class, she sought admission to the University of Georgia in Athens, which had a strong journalism program. The school did not admit African Americans, and Ms. Hunter-Gault initially was denied entrance, beginning her college career at Wayne State University. The admissions decision was challenged successfully in court. Ms. Hunter-Gault became the first African American woman to enroll at the University of Georgia, and one of two students who integrated the school. Arriving on campus, they were greeted by a hostile mob, suspended from school "for their own safety," and ultimately reinstated by court order. Despite these experiences, she later established a scholarship for African American students at the University of Georgia, and was a graduation speaker. A building a campus bears her name.

After graduation, Ms. Hunter-Gault embarked on a distinguished career in journalism that was profoundly influenced by experience at UGA, including coverage of the story by top journalists of the day. She worked at the New Yorker magazine, was a Russell Sage Fellow, and became a reporter and anchor at WRC-TV in Washington, DC. She went on to establish the Harlem bureau of the New York Times, and in 1978 became a national correspondent and anchor at PBS's MacNeil/Lehrer Report, which later became the NewsHour. From 1999 to 2005, she served as CNN's network bureau chief and correspondent in Johannesburg, South Africa. Ms. Hunter-Gault was recognized with a Peabody Award for her four-part PBS series, Apartheid's People, which details life in South Africa under apartheid. She earned another Peabody for her coverage of Africa, as well as two Emmy Awards for her television work. She continues to inspire through her writing, television and radio reporting and commentary, and personal appearances. Ms. Hunter-Gault has chronicled her life and work in three books: In MyPlace, New News Out of Africa: Uncovering the African Renaissance; and To the Mountaintop: My Journey Through the Civil Rights Movement.

\section{BOOK AWARDS}

\section{Ralph J. Bunche Award}

The Ralph Bunche Award is given annually for the best scholarly work in political science that explores the phenomenon of ethnic and cultural pluralism.

Award Committee: Alvin Tillery,Jr., Northwestern University, Chair; Vanna Gonzales, Arizona State University; Lynn Sanders, University of Virginia

\section{Recipient: Traci Burch}

Title: Trading Democracy for Justice:Criminal Convictions and the Decline of Neighborhood Political Participation

Citation:In Trading Democracy for Justice, Traci Burch explores the political costs that flow from the fact that the United States of America incarcerates far more people than any other nation in the world. Whereas social scientists have long argued that individuals who experience incarceration often have difficulty participating in our political system upon their release, Burch's book is the first to demonstrate how mass incarceration in the United States yields negative externalities that demobilize entire communities. Through innovative data collection in neighborhoods with the highest imprisonment rates in America, Burch shows that overall citizens living in these communities participate in politics less than their fellow Americans even when they themselves have not been incarcerated. Burch also shows that rates of civic engagement and volunteerism are lower in these high-incarceration neighborhoods. Burch persuasively argues that the fact that these neighborhoods are disproportionately minority and poor means that America's commitment to policies of mass incarcerations reinforces preexisting racial and class inequalities. The commit- tee deemed this book worthy of the Bunche Award because we were incredibly impressed with the rigor of Burch's empirical analyses of this pressing problem, the strong theoretical contributions that she makes to the field of political behavior, and the engaging and lyrical quality of her writing.

Recipients: Natalie Masuoka, Tufts University; and Jane Junn, University of Southern California

Title: The Politics of Belonging: Race, Public Opinion, and Immigration

Citation: In The Politics of Belonging, Natalie Masuoka and Jane Junn explore American attitudes on immigration. Whereas most public opinion studies of the immigration issue in American politics attempt to discern the levels of nativism extant within certain demographic groups in a particular historical moment, Masuoka's and Junn's book moves beyond this approach in two innovative ways. First, Masuoka's and Junn's book demonstrates that public opinion about immigration is connected to the historical development of immigration laws and the process of racial formation in the United States. Second, Masuoka and Junn engage in comparative analysis of public opinion among African Americans, Asian Americans, Latinos, and white Americans to show how racial categorization and group identity affect public opinion on immigration. As a result of this "Racial Prism" analysis, Masuoka and Junn are able to demonstrate that American attitudes about immigration are often the product of our national debates over race, citizenship, and who "belongs" within the polity. The committee deemed this book worthy of the Bunche Award because we were very impressed by Masuoka's and Junn's innovative theoretical interventions, the historical sweep of the work, and the book's sophisticated methodological approach.

\section{Gladys M. Kammerer Award}

The Gladys M. Kammerer Award is given annually for the best book published during the previous calendar year in the field of U.S. national policy.

Award Committee: Bryan D. Jones, University of Texas, Chair; Cindy D. Kam, Vanderbilt University; Gregory Koger, University of Miami

Recipient: Nicholas Carnes, Duke University

\section{Title: White-Collar Government}

Citation: In White Collar Government, Nicholas Carnes returns to long-neglected issue that once preoccupied many political 
scientists-the extent to which the class compositions of our governing institutions differ from that of the broader public and to what effect. Like the earlier scholars, Carnes finds vast underrepresentation of working class citizens. Unlike the earlier generation, Carnes explores what differences this imbalance makes in the policymaking process and political outcomes. White Collar Government artfully employs an eclectic research strategy that explores policymaking mechanisms at different levels of government. With skillful analysis, lucid presentation, and stimulating prose, Carnes convinces the reader that differences in class composition of legislatures make big differences in intermediate successes, such as attracting bill co-sponsors, and ultimately in policy outcomes.

By itself, White Collar Government makes an exciting contribution - one that is likely to stand the test of time. In addition, the best books in political science also raise important questions that demand additional investigation. What patterns of recruitment and campaigning explain the election of working class Americans in politics in the first place? Do working class legislators influence deliberation on economic issues in committees or legislative chambers? To what extent do political parties compensate for the underrepresentation of working class Americans in Congress and state legislatures? We expect that White Collar Government will provide a rich foundation for further research on class and representation.

\section{Victoria Schuck Award}

The Victoria Schuck Award is given annually for the best book published on women and politics.

Award Committee: Susan Bickford, University of North Carolina, Chair; Kathleen Bratton, Louisiana State University; Sarah Wiliarty, Wesleyan University

Recipient: Deborah Jordan Brooks, Dartmouth College

Title: He Runs, She Runs: Why Gender Stereotypes Do Not Harm Women Candidates

Citation: In He Runs, She Runs, Deborah Jordan Brooks investigates the conventional wisdom that female candidates are negatively impacted by gender stereotypes and gendered standards of evaluation. The book is distinctive for its application of the experimental method, by which Brooks avoids the methodological problems with relying on survey questions about gender or on anecdotes about actual candidates. Her elegantly designed experiment, on a large representative sample of adults, produces intriguing and counterintuitive findings about the public's perceptions of female candidates. The analysis shows that female candidates are not penalized disproportionately to male candidates with respect to self-presentation (tough vs. caring), emotional displays (crying, anger) or "knowledge gaffes." This illuminating, insightful, and carefully argued book represents a major contribution to the literature on gender in elections. As Brooks makes clear, the study has practical implications as well. The conventional wisdom that the public is harder on female candidates may be responsible for the "ambition gap" that leads women to be less likely to run for office. Correcting this view of candidate perception can thus play a role in moving us toward gender parity in representative institutions. This innovative study deserves a wide readership and is a worthy recipient of the Victoria Schuck award.

\section{Woodrow Wilson Foundation Award}

The Woodrow Wilson Award is given annually for the best book on government, politics, or international affairs. The award is sponsored by the Woodrow Wilson Foundation at Princeton University.

Award Committee: Dean Lacy, Dartmouth College, Chair; Thomas Dumm, Amherst College; Rose McDermott, Brown University

Recipient: Ira Katznelson, Columbia University

Title: Fear Itself: The New Deal and the Origins of Our Time

Recipient: Denise Kiernan, Journalist Title: The Girls of Atomic City: The Untold Story of the Women Who Helped Win World War II

Citation: Both books trace contemporary politics to the economic, social, and international upheaval of the era spanning the Great Depression through World War II. Ira Katznelson, a political scientist, analyzes the international and domestic politics that forged the era. Denise Kiernan, a journalist, documents the lives of a group of women ignored by history but who lived the politics of the era through their crucial work on the Manhattan Project.

Ira Katznelson's Fear Itself is a richly detailed political analysis of three struggles that preceded World War II: an international struggle between democracy and authoritarianism as regimes for safeguarding a nation's security, a technological struggle over the rapidly advancing weapons of war, and a domestic struggle over race in the American South.
These three struggles forged the politics of the New Deal and continue to influence US and world politics today. Internationally, US policies during WWII proved that democracies could compete with dictatorships in providing for national security, a proposition that was in doubt before and during the war. Technologically, advances in the capacity and complexity of weapons of war compelled the US to maintain a large military, even in peacetime, and abandon the isolationism that defined earlier eras of American politics. In domestic politics, much of the New Deal would not have passed Congress without the support of Southern legislators, who insisted that New Deal programs protect segregation and funnel federal dollars to the South. The result of this bargain continues to shape US fiscal policy. Katznelson adds much that is new to the library of books on the New Deal, and Fear Itself is one of the most important books ever written on American political development.

Denise Kiernan's The Girls of Atomic City tells the story of the women who developed the raw material for the atomic bomb in Oak Ridge, Tennessee, during WWII. The work of the men who designed the atomic bomb at Los Alamos has been well documented. But history has largely ignored the work at the Manhattan Project's headquarters in Oak Ridge, where thousands of women produced and protected the material that made the bomb possible. The women came from all over the United States to a small Southern town to work on a closely guarded secret that would redefine warfare and reshape the global order. Their work was demanding, technically complex, and vital to the US war effort, but their stories have been kept almost as secret as the work they did during the war. The book is about more than the women or the weapon they built. Denise Kiernan's interviews with the women who worked at Oak Ridge situate their daily lives in the broader political contexts of war, segregation, secrecy, the changing American South, and the changing role of women in wartime and the economy. Kiernan has contributed a new and vital chapter to studies of American political development and woman and politics.

The two books cover many of the same issues - WWII's pivotal role in American political development, trade-offs between freedom and national security, and race - but from two different and equally informative perspectives. Both books, in their own ways, advance an important theme in the study of politics: human beings and their narratives 
inform much of what we can learn about the exercise of power and its ends.

\section{DISSERTATION AWARDS}

\section{Gabriel A. Almond Award}

The Gabriel A. Almond prize is awarded annually for the best dissertation in the field of comparative politics.

Award Committee: Alberto Diaz-Cayeros, Stanford University, Chair; Brian Burgoon, University of Amsterdam; Wenfang Tang, University of Iowa

Recipient: Regina Bateson, Princeton University

Title: "Order and Violence in Postwar Guatemala"

Citation: The committee was truly impressed by the quality of the submissions, a reflection of a thriving field in comparative politics. All the dissertations we read employed sound theoretical frameworks, sophisticated empirical analyses and engaged important questions. But one work stood out from the very beginning. Regina Bateson has written a truly extraordinary piece. Her dissertation reports findings emerging from a nuanced and profound study of violence and vigilantism in a postconflict society, namely Guatemala. While the civil war literature has been mostly concerned with understanding the conditions and consequences of insurgencies, Bateson has written the first comprehensive study of the legacies of civil war and how they determine the way in which societies deal with the challenge of providing citizen security. The story that emerges from this study is not pretty-violence never is, no matter how academically attractive the current trend of scholarship on these issues might be. In the absence of a strong state, capable of curtailing violence, Bateson demonstrates that communities tolerate public displays of extreme violence -lynching by vigilantes, which has a deterrent effect on crime. Paradoxically, this communal violence is less likely to arise in places that experienced the most acute levels of civil war violence. In regions where these exemplary punishments do not occur, murder rates are higher, because interpersonal violence remains a common experience in the everyday life of citizens. "Order and Violence in Postwar Guatemala" is written with a remarkable passion and maturity for a dissertation. The collection of original data is impressive. The protocol to protect enumerators provides an important guideline on how to conduct ethical research in perilous places. The municipal level analysis makes use of the latest advances in statistics and Geographic Information Systems. And the theory poises challenging questions to several areas in comparative politics. In sum, beyond an excellent case study, this will be a lasting contribution to the study of violence and public security in developing countries.

\section{William Anderson Award}

The William Anderson prize is awarded annually for the best dissertation in the general field of federalism or intergovernmental relations, state and local politics.

Award Committee: Seth Masket, University of Denver, Chair; Kenneth N. Bickers, University of Colorado; Eric Plutzer, Pennsylvania State University;

Recipient: Steven Rogers, Princeton University

Title: "Accountability in a Federal System"

Citation: Steven Rogers' dissertation, "Accountability in a Federal System," investigates voters' ability to hold state legislators and parties accountable for their behavior in office. Rogers' assessment is a somewhat bleak one; not only do nearly a third of state legislators face no challenger at all in a given election, but those that do are rarely evaluated on the basis of policy outcomes or their own legislative behavior. Indeed, state politics appears to be largely dominated by national events, with the popularity of the president largely determining how state legislative parties will fare in the next election cycle. Rogers' incisive use of roll call voting data, election returns, and survey responses ultimately calls into question citizens' capabilities as monitors of officeholders and produces a thoughtful and important discussion about just what role democracy should demand from voters.

\section{Edward S. Corwin Award}

The Edward S. Corwin prize is awarded annually for the best dissertation in the field of public law.

Award Committee: Tom Clark, Emory University, Chair; Katy Harriger, Wake Forest University; Robert Seddig, Allegheny College

Recipient: Rachel Hinkle, Washington University, St. Louis

Title: "The Role of the United States Courts of Appeals in Legal Development"

Citation: Rachel Hinkle (Washington University of St. Louis) received the Edwin S. Corwin Award which recognizes the best doctoral dissertation in the field of public law. Professor Hinkle's "The Role of the United States Courts of Appeals in Legal Development" is a clearly written, cogently argued, and creatively conceptualized study of how legal factors constrain Court of Appeals decision making and how Court of Appeals decisions impact state government policy choices. Demonstrating an astute understanding of the existing literature on legal development and Courts of Appeals, Hinkle moves this research forward through three major chapters addressing different aspects of her topic. In the first, she explores the question of whether legal factors constrain judges. She distinguishes between "binding" precedent within the circuit and "persuasive" precedent from other circuits and asks whether the former acts as a greater constraint on judges than the latter. Using an impressive data set made up of judges' citation choices she finds that judges cite and interpret precedent more ideologically when it is out of circuit than when it is binding. In the second main essay she uses the same citation data to ask whether judges act strategically in anticipation of en banc review. Using a statistical model that relies on the ideological location of the precedent, the judge, and the median judge in the Circuit, she makes a persuasive case for strategic behavior in the use of precedent on three judge panels. The third essay focuses on how Court of Appeals decisions contribute to legal development outside of the courts. She uses computational text analysis of state legislation and court opinions to demonstrate that circuit court decisions do impact state legislative action. This dissertation is an impressive piece of work about an important level of courts, which she appropriately notes handles far more cases than the Supreme Court and thus must surely play a substantial role in the development of the law. It demonstrates sophisticated understanding of the existing literature and novel methodological approaches to answering important questions in the field.

\section{Harold D. Lasswell Award}

The Harold D. Lasswell prize is awarded annually for the best dissertation in the field of public policy. The award is co-sponsored by the Policy Studies Organization.

Award Committee: Elaine Sharp, University of Kansas, Chair; Michael Rich, Emory University; Max Skidmore, University of Missouri

Recipient: Sarah Anzia, Stanford University

Title: "Election Timing and the Political Influence of the Organized"

Citation: Sarah Anzia's dissertation (at Stanford University) "Election Timing and the Political Influence of the Organized" 
focuses on an intriguing and highly important feature of American politics: the election of most sub-national government officials in elections off-cycle (i.e., non-concurrent with) national-level presidential elections. This institutional arrangement is known to yield lower turnouts. Anzia's dissertation not only demonstrates just how large this turnout differential is; it goes beyond such description to theorize about how election timing affects the composition of the electorate, election outcomes, and public policy. Specifically, she hypothesizes that low voter turnout in off-cycle elections increases the electoral influence of organized interest groups, for two reasons: the large stakes that such groups have trumps the usual effect of election timing and low turnout enhances the effectiveness of interest groups' mobilization efforts. The dissertation then turns to a logically derived set of empirical investigations of the politics of decision-making about election timing and the effects of election timing on policy outcomes. To do this, she draws upon a wide range of data sources, including an original database of painstakingly collected state election administration data, survey data from a nationally representative sample of adults, historical research on multiple cities, and secondary materials from political science and history. The result is a dissertation that convincingly demonstrates that off-cycle election timing yields public policy that is more favorable to interest groups, and that this leads interest groups that benefit from off-cycle elections to fight vigorously to keep it.

It is a mark of the significance and quality of Anzia's dissertation that it has already been published by the University of Chicago Press, with the title "Timing and Turnout: How Off-Cycle Elections Favor Organized Groups.” This imaginatively designed and well-written dissertation epitomizes the significant insights about public policy that the Lasswell Award is meant to acknowledge.

\section{Helen Dwight Reid Award}

The Helen Dwight Reid prize is awarded annually for the best dissertation successfully defended during the previous two years in the field of international relations, law, and politics.

Award Committee: Deborah Welch Larson, University of California, Chair; James McAllister, Williams College; Kristopher Ramsay, Princeton University

Recipient: Joshua David Kertzer, Ohio State University
Title: "Resolve in International Politics"

Citation: It was a difficult decision because of the strong set of submissions, but the committee selected Joshua Kertzer's dissertation, "Resolve in International Politics" because of its theoretical richness, conceptual elaboration, ambition, and methodological sophistication. Kertzer's committee was chaired by Professor Richard K. Herrmann of Ohio State University. Why do some states persist in war, despite the loss of many casualties, while others seek a settlement? Although it might seem that resolve is well-understood in light of the huge literature on crisis bargaining, Professor Kertzer convincingly shows that the prevailing conceptualization of resolve is inadequate to distinguish it from capabilities and intentions. Without understanding what resolve is, it is impossible to measure the concept or test its effects. He then shows the relevance of psychological theory on will power, a perspective that has not previously been applied to strategic analysis. Kertzer argues that resolve is a function of the interaction between psychological dispositional characteristics-time and risk preferences, concern for honor, and self-control-and situational incentives. He tests his ideas with a combination of methods-beginning with a laboratory experiment to identify the psychological traits that are associated with continued support for military intervention in the face of rising costs, followed by a survey experiment with a nationally representative sample. He then applies his theory to a Boolean statistical analysis of great power interventions from 1946-2003 to determine if resolve is associated with victory. Finally, his writing style is dazzling, with colorful language and interesting anecdotes that entice the reader to grapple with complex ideas.

\section{E.E. Schattschneider Award}

The E.E. Schattschneider prize is awarded annually for the best doctoral dissertation completed and accepted during that year or the previous year in the field of American government.

Award Committee:Jamie L. Carson, University of Georgia, Chair; James S.C. Battista, SUNY, University at Buffalo; Cheryl Boudreau, University of California

Recipient: Sarah Anzia, Stanford University

Title: "Election Timing and the Political Influence of the Organized"

Citation: Sarah Anzia's dissertation represents an important contribution to the field of American politics. Her research is motivated by an important but often overlooked feature of the American electoral system: a sizable majority of America's elected officials are selected on days other than the first Tuesday after the first Monday in November of even-numbered years. As is generally recognized by academics and pundits alike, voter turnout in off-cycle elections is typically much lower than in those elections held concurrently with U.S. presidential elections. This has important implications for public policy since far fewer voters participate in elections for down-ticket races.

Sarah begins her dissertation by discussing the intricacies of differential election timing and then evaluates the consequences of the variance in participation at various levels within the electoral system. Along the way, she offers an extremely compelling argument about how organized interests are advantaged as a result of the election timing in the U.S. In short, interest groups take advantage of the low voter turnout that accompanies off-cycle election timing since it significantly influences their electoral influence. Not only are organized interests more likely to participate in elections regardless of when they are held, but they also work hard to mobilize their supporters. This, in turn, increases the electoral benefits for interest groups in lowturnout contests since so few other voters are actively supporting the candidates for elective office.

A substantial portion of Sarah's dissertation involves a series of empirical tests of both the effects of election timing on public policy and a discussion of how state legislatures choose when off-cycle elections will be held. Sarah incorporates a wide variety of data sources in her dissertation including historical research from a variety of states and cities, survey data from a national sample of adults, administrative data from multiple cities, and a host of secondary materials. The quality of the argument and evidence is quite compelling. Sarah makes a very strong case that organized interests benefit from the timing of off-cycle elections and they have a vested interest in maintaining the status quo to ensure that they continue to exert influence in the policy making process. Not surprisingly, this has important implications for representation and democracy within the American electoral system.

Sarah's dissertation offers a persuasive narrative with a novel argument and convincing evidence. For those interested in learning more about this project, her dissertation was recently published as a book, 
Timing and Turnout: How Off-Cycle Elections Favor Organized Groups and is currently available from the University of Chicago Press.

\section{Leo Strauss Award}

The Leo Strauss prize is awarded annually for the best dissertation in the field of political philosophy.

Award Committee: Eve Grace, Colorado College, Chair; Laurence Cooper, Carleton College; Murray Jardine, Auburn University

Recipient: Adam Sandel, University of Oxford

Title: "The Place of Prejudice"

Citation: In :The Place of Prejudice" Adam Sandel makes a welcome contribution to the reconstruction of political rationality. Drawing primarily upon the (now often-ignored) earlier writings of Martin Heidegger and the hermeneutic theory of Hans-Georg Gadamer, as well as upon Aristotle's account of phronesis, Sandel seeks to show that not only is prejudice, or pre-judgement, inevitable, it is indeed an integral source and component of reason. He critiques both the Enlightenment conception of unprejudiced knowledge and Edmund Burke's anti-rationalist defense of prejudice, and then shapes particular insights from Heidegger, Gadamer, and Aristotle into a theory of epistemological prejudice with notable practical and moral significance. Sandel ultimately indicates that grounding rationality in prejudice does not necessarily have "conservative" political implications.

\section{Leonard D. White Award}

The Leonard D. White prize is awarded annually for the best dissertation successfully defended during the previous two years in the field of public administration.

Award Committee: Steven Balla, George Washington University, Chair; Kendra Stewart, College of Charleston; Alan Wiseman, Vanderbilt University;

Recipient:Viridiana Rios Contreras, Harvard University

Title: "How Government Structure Encourages Criminal Violence: The Causes of Mexico's Drug War"

Citation: The 2014 Leonard D. White Award Committee is pleased to announce the selection of Viridiana Rios Contreras's dissertation as the recipient of this year's award. In her dissertation, Rios examines the institutional foundations of the tragic explosion of drug-related violence that has plagued Mexico in recent years. Rios's theoretical perspective runs counter to the conventional wisdom that the recent outburst has occurred as a violent reaction to an increase in central government enforcement. Rios demonstrates that, to the contrary, drug cartel violence has been a response to decentralization in the Mexican government. In this decentralized institutional environment, drug cartels have had incentives to arm themselves and increasingly engage in criminal activities such as extortion, kidnapping, and murder. In staking this most salient claim, Rios brings together insights drawn from a formal model, an analytical narrative, and a statistical test. Together these approaches highlight the importance of government institutions in mediating not only enforcement capacity, but also compliance on the part of criminal organizations.

\section{PAPER AND ARTICLE AWARDS}

\section{Franklin L. Burdette Pi Sigma Alpha Award}

The Franklin L. Burdette Pi Sigma Alpha prize is awarded annually for the best paper presented at the previous year's annual meeting. The award is supported by Pi Sigma Alpha.

Award Committee: Kenneth A. Schultz, Stanford University, Chair; Paul Djupe, Denison University; Guillermo Rosas, Washington University

Recipient: Chad P. Kiewiet de Jonge, Center for Economic Research and Teaching

Title: "Political Learning and Democratic Commitment in New Democracies"

Citation: We are delighted to award the Franklin L. Burdette prize to Chad Kiewiet de Jonge for his paper "Political Learning and Democratic Commitment in New Democracies." This paper explores interpersonal and cross-national variation in mass commitment to democratic values and institutions in Latin America. On the theoretical side, it impressively draws together literatures on socialization and political learning and ties them to theories of political preference formation, such as modernization theory and retrospective voting. A key question is the extent to which commitment to democracy depends on early exposure to pro-democratic values during an individual's formative years or on evaluations of government performance, which tend to emphasize recent outcomes. Kiewiet de Jonge proposes a "lifetime learning" model that flexibly allows citizens' current attitudes to be influenced by both early exposure to pro-democratic or modernizing values and more recent government performance in delivering economic growth and civil and international peace.
The empirical analysis, based on survey data from 18 countries in the period 2004-2010, yields a rich set of results, some anticipated, some more surprising. Of particular interest are the pro-democratic effects of economic growth and low levels of violence during a respondent's early years (i.e., before age 26), which Kiewiet de Jonge interprets as a persistent influence of exposure to modernizing conditions. The results also show that more recent government performance on these dimensions improves democratic commitment but not, surprisingly, in a way that is conditional on regime. That is, recent experience with peace and prosperity increases democratic commitment even when the regime in power is autocratic. Kiewiet de Jonge also shows that some aspects of performance have different impacts on individuals depending on social class and political ideology. For example, economic growth has a stronger effect on the democratic commitment of those on the left than of those on the right; this, he suggests, might explain why democratic commitment is strong on the left in relatively well-developed countries but stronger on the right in poorer countries. The paper is well-crafted and very clearly argued. Moreover, Kiewiet de Jonge is appropriately careful in his interpretation of the empirical results, giving due consideration to those that were unexpected or hard to explain. The paper's powerful method and rich results are certain to generate ongoing interest among scholars of democratic development and political learning.

\section{Heinz I. Eulau Award}

The Heinz Eulau prize is awarded annually for the best article published in the American Political Science Review and for the best article published in Perspectives on Politics in the calendar year. Two Eulau Awards are made, one for each journal. Committee members are asked to help make the selection from one journal or the other, and the chair is asked to participate in both decisions.

Award Committee: Edward D. Mansfield, University of Pennsylvania, Chair; Sarah Brooks, Ohio State University, Perspectives; Laura Woliver, University of South Carolina, Perspectives; Laura Stephenson, University of Western Ontario, American Political Science Review (APSR); Nathan W. Monroe, University of California, Merced, APSR

Recipients: Jacob S. Hacker, Yale University; Phillip Rehm, Ohio State University; and Mark Schlesinger, Yale University 
Title: "The Insecure American: Economic Experiences, Financial Worries, and Policy Attitudes." Perspectives on Politics. 11 (1) 23-49.

Recipient: Dara Kay Cohen, Harvard University

Title: "Explaining Rape during Civil War: Cross-National Evidence (19802009.)" American Political Science Review 107( 3): 461-77.

Citation: The prize for the best article in Perspectives on Politics will go to: Jacob S. Hacker, Philipp Rehm, and Mark Schlesinger, for "The Insecure American: Economic Experiences, Financial Worries, and Policy Attitudes," 11 (1): 23-49. This article provides fresh perspective on how Americans understand and experience economic insecurity, and how such insecurity affects their policy attitudes. The authors have conducted an impressive and original survey of Americans during the height of the Great Recession, the Survey of Economic Risk Perceptions and Insecurity. Their analysis of this survey reveals that "Citizens' economic worries largely track exposure to substantial economic shocks. Citizens' policy attitudes in turn appear highly responsive to economic worries, as well as to economic shocks-with worries and shocks creating greater support for government policies that buffer the relevant economic risks." Their innovative approach moves beyond static measures of income to include vulnerability to shocks based not attitudes as well as access to private buffers. By shining new light on the links between economic shocks, attitudes across four policy domains (employment, health, family and wealth), and individual economic security, Hacker, Rehm, and Schlesinger make a significant contribution to our understanding of American political attitudes and behavior. Their findings offer a basis for future research that will expand our knowledge of the nexus of individual and mass opinion in an evolving economy.

The prize for the best article in the American Political Science Review will go to Dara Kay Cohen, "Explaining Rape during Civil War: Cross-National Evidence (1980-2009)," Vol. 107 (3): 461-77. This article argues that rape can be used to promote combat socialization during civil wars. Cohen collects a highly original data set and finds substantial variation in wartime rapes both across and within civil conflicts. She finds little support for explanations of this variation that emphasize opportunism, ethnic hatred, and gender inequality. Instead, Cohen argues, variation in wartime rape stems from the tendency to use rape to socialize new members of armed groups that have been forcibly conscripted. As she puts it, "Rape-especially gang rape-enables groups with forcibly recruited fighters to create bonds of loyalty and esteem from initial circumstances and mistrust." Cohen marshals support for this argument by deftly combining a statistical analysis of her original dataset and field work in Sierra Leone with ex-combatants. This article is notable for the importance of the topic, its originality, its seamless integration of gender research into the study of civil violence, and its likely impact on future research on civil war.

Honorable Mention for the best article in the American Political Science Review will go to Lisa Blaydes and Eric Chaney, "The Feudal Revolution and Europe's Rise: Political Divergence of the Christian West and the Muslim World before 1500 CE," 107(1) 16-34. This article identifies a heretofore unexplored difference in the duration of rule for monarchs in Western Europe and the Islamic world from 1100 to $1500 \mathrm{CE}$. With a broad historical sweep, the authors argue that "decentralizing power increases the cost of an unsuccessful revolt for the monarch's rivals." Armed local elites were able to obtain better terms in Western Europe than in the Islamic world and therefore had less incentive to overthrow the monarch. As such, Western European rulers enjoyed longer tenures than their Muslim counterparts. Blaydes and Chaney's study is bold, highly original, and makes an important contribution to the study of political development and historical institutional approaches to comparative politics. 